\title{
LA CEGUERA EN LA OBRA DE E. SABATO: EL INFORME SOBRE CIEGOS
}

\author{
LOSCOS-ARENAS J ${ }^{1}$, DE-LA-CÁMARA J ${ }^{2}$
}

La utilización de la ceguera como metáfora es un recurso frecuente tanto en prosa como en poesía. El «ver» o el «no ver» (la ceguera) son temas constantes en la literatura y se convierten en el más sublime de los deseos o en la peor de las pesadillas. En poesía como ejemplo del «querer ver»y del «no ver» es el famoso soneto de «La vida es sueño» (P. Calderon de la Barca, 1620) donde un apasionado Segismundo desea unos ojos «hidrópicos» para ver una y mil veces a su amada Rosaura pese al dolor que ello le causa (1).

En la novela contemporánea la ceguera como metáfora es también un recurso frecuentado por muchos autores. Pero los males que la «ceguera» suponen para el hombre moderno, es especialmente importante en la breve pero intensa obra de Ernesto Sábato (Buenos Aires, 1911). La ceguera física se relaciona con la moral y más allá de la simbología psicoanalista, la figura del ciego representa nuestros miedos e incapacidades tanto individuales como colectivas. Alejandra y Martín junto a Fernando Vidal Olmos, son los protagonistas de «Sobre Héroes y tumbas, 1961» (2) y el último encarna como ningún otro personaje su recurrente obsesión por la ceguera que alcanza su climax en el «Informe sobre ciegos». Es el hombre que debe esforzarse por ver y

\author{
«Ojos hidrópicos creo \\ que mis ojos deben ser, \\ pues, cuando es muerte el beber, \\ beben más, y desta suerte, \\ viendo que el beber me da muerte, \\ estoy muriendo por ver. \\ Pero véate yo y muera; \\ que no sé, rendido ya, \\ si el verte muerte me da, \\ el no verte qué me diera».
}

Fig. 1: La Vida es Sueño. Pedro Calderón de la Barca. de superar «su ceguera» para mejorar como persona e intentar alcanzar la verdad aunque ésta sea inalcanzable. Sus personajes son fruto de los miedos del autor y como él mismo dice «Los seres humanos no pueden representar nunca las angustias metafísicas al estado de puras ideas sino que lo hacen encarnándolas». Los ciegos, «la secta», tienen una presencia oscura y fantasmagórica en su obra y nos alerta de que cualquiera de nosotros

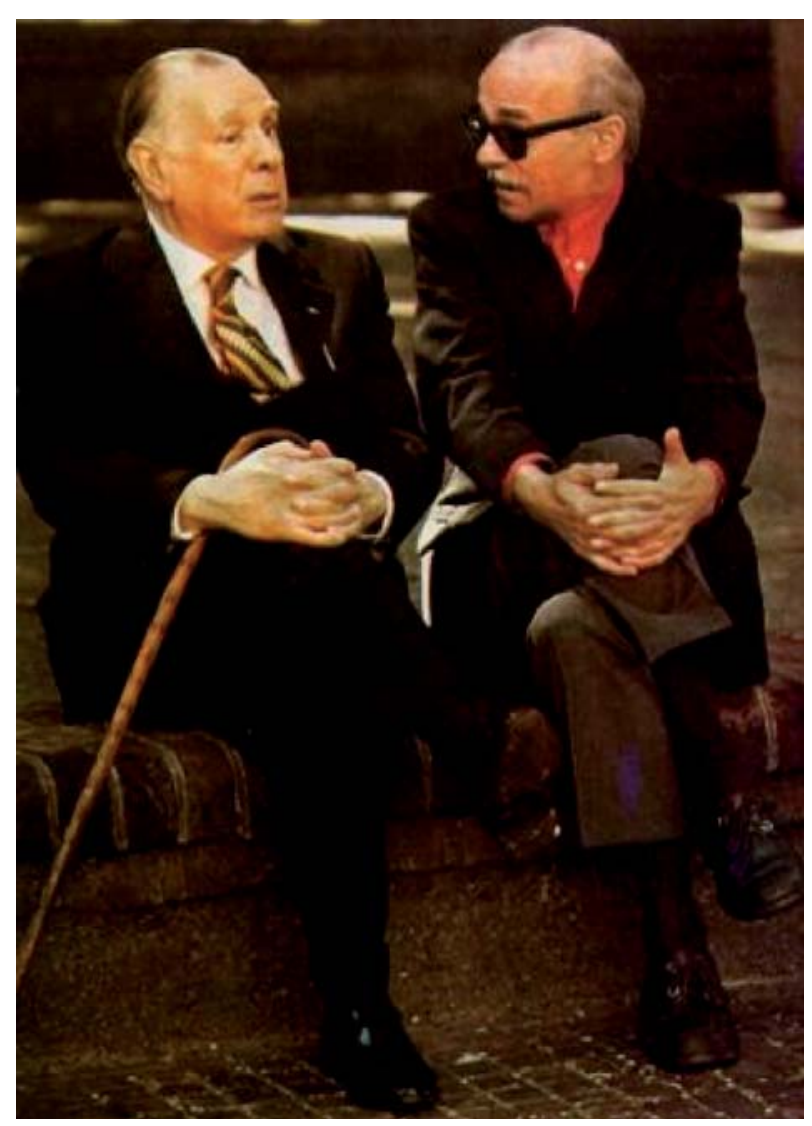

Fig. 2: Ernesto Sábato y Jorge Luis Borges.

\footnotetext{
Servicio de Oftalmología. Hospital Universitari «Germans Trias i Pujol». Badalona. Barcelona.

${ }^{1}$ Licenciado en Medicina.

2 Doctor en Medicina.

E-mail: jordiloscos4@hotmail.com
} 
podemos ser victimas de «los ambiguos mecanismos de la secta». Puede que sí y seguramente todos somos víctimas potenciales pues vivimos en una sociedad donde la tecnología nos avasalla cada vez más. Es por ello que Sábato, inicialmente hombre de ciencia, que cursó su doctorado en Física y trabajó en el Laboratorio Curie, la abandona decepcionado y de manera definitiva en 1945 para dedicarse a la literatura. Desde su propia experiencia nos avisa de que la tecnología esclaviza y robotiza al ser humano, y que no hay progreso tecnológico que valga la pena si no va de la mano de una superación moral y espiritual.

El hombre actual, en todos los campos de la ciencia y especialmente en medicina ha alcanzado un desarrollo tecnológico sin igual, pero ¿hemos progresado de igual manera en el conocimiento humano que en el tecnológico? Cada vez «vemos» más mundo y cada vez «vemos» más medicina pero por el excesivo protagonismo de la tecnología en nuestra profesión corremos el riesgo de «mirar sin ver». Y ese es uno de los retos que el médico al igual que los personajes de Sábato tiene ante sí: «aprender a ver».

La figura de Sábato, pese a su controvertido papel en la dictadura de Videla es un referente ético en Argentina para las nuevas generaciones. Paradojas de la vida, actualmente vive retirado, disminuido por su ceguera, lo que le ha obligado a abandonar la literatura. Su último libro de memorias «Antes del fin» (1999) está escrito para los que como él «se preguntan para qué hemos vivido y aguantado, soñado, escrito, pintado o, simplemente, esterillado sillas» (3).

\section{BIBLIOGRAFÍA}

1. Calderón de la Barca P. La vida es Sueño. Madrid: Clásicos Castalia. 2000.

2. Sabáto E. Sobre héroes y tumbas. Barcelona: Ed. Seix Barral. 2001.

3. Sabáto E. Antes del fin. Memorias. Barcelona: Ed. Seix Barral. 1999. 